\title{
Jane Diplock
}

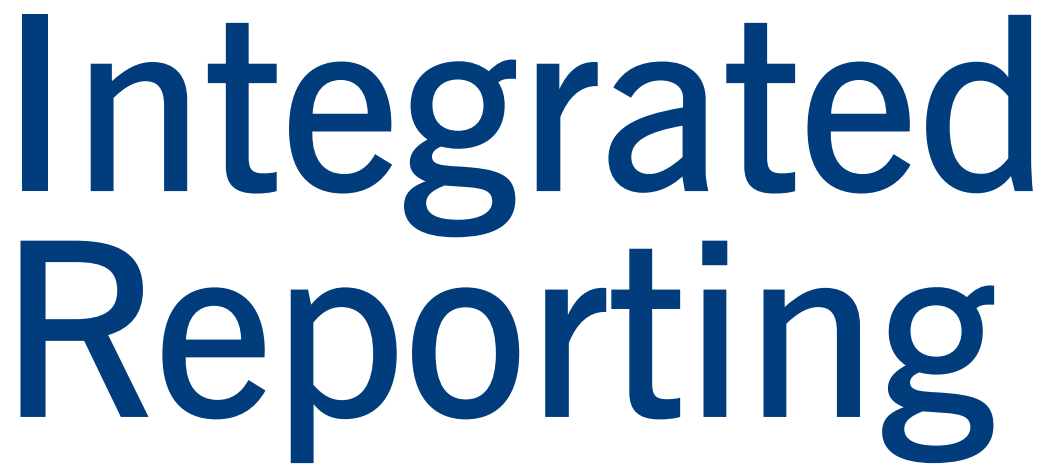

what is it and why should you do it?

\section{Around the world, increasing numbers of businesses are} evolving their strategic thinking, planning and reporting practices. Business practices are undergoing rapid change and as a result businesses are concluding that reporting must also change.

Disruptive business models, new technologies, increasing globalisation and big data are all having very real effects on how companies think, plan and report. We know that up to $80 \%$ of the value of a business today is accounted for by intangible factors, such as its intellectual property, productivity rates, brand and reputation (Ocean Tomo, 2017). In the past, conversations around board tables and between investors and businesses focused almost exclusively on financial and manufactured capital. This limited focus and lack of transparency around the business model and its sustainability has led to a loss of trust between businesses, their shareholders and other stakeholders. It is increasingly important that this conversation be expanded to take into relationship, and natural capital.

As set out in the International $<\mathrm{IR}>$

Framework, integrated reporting is account human, intellectual, social and

Jane Diplock AO is the Chair of the Governance and Nominations Committee of the International Integrated Reporting Council.

consistent with developments in financial and other reporting, but an integrated report also differs from other reports and communications in a number of ways. In particular, it focuses on the ability of an organization to create value in the short, medium and long term, and in doing so it has a combined emphasis on conciseness, strategic focus and future orientation, the connectivity of information and the capitals and their interdependencies.

It also emphasises the importance of integrated thinking within an organisation, which is the 'active consideration by an organization of the relationships between its various operating and functional units and the capitals that the organization uses or affects' (International Integrated Reporting Council, 2013, p.2).

The $<\mathrm{IR}>$ Framework is principlesbased, establishing guiding principles and core content elements for reporting. As such, companies will likely use other standards to develop data and key performance indicators that users will be looking for. Investors and other stakeholders make better decisions when they have access to information about 
strategy, the business model, and the risks and opportunities the business is facing, and when they are given insights into management's thinking.

Modern, well-run and well-governed companies want to enhance trust and are thinking strategically across the full breadth of these vital issues to address the challenges, risks and opportunities these changes present. The results of this strategic approach are reflected in an explanation of how a business model creates value over the short, medium and long term and are reflected in an integrated report.

In over 60 countries, more than 1,500 reporting. We are hearing stories all the time of the very real impact integrated reporting is having on our markets.

\section{Research evidence}

Research conducted by the National University of Singapore examined the performance of 80 companies across the APEC economic region: 40 companies that had adopted integrated reporting and 40 companies that had not. Over a four-year period, every one of the 40 companies that had adopted integrated reporting outperformed their peers and benefited from a lower cost of capital (National University of Singapore and

\section{The biggest drive for its adoption has come in markets where it is recognised as an essential and inseparable part of corporate governance.}

organisations are now producing integrated reports, with uptake growing rapidly each year (Corporate Register, 2017). The International Integrated Reporting Council (IIRC), which I have been closely involved with since its inception in 2010, is leading this evolution in reporting. We are working to ensure that capital allocation decisions support trust, financial stability and sustainable development. It is not an easy task, but the evidence of early adoption suggests that the impact of changing the way a business thinks and reports is significant.

Let me give a few examples. Anglo African, a small-to-medium enterprise, realised through the process of adopting integrated reporting that its business model was too short-term and that it was likely to fail if it didn't find more long-term solutions. The Malaysian energy giant Petronas Gas now receives a lower rate of interest on a loan from a Japanese bank because it is implementing integrated reporting. The Royal Bank of Scotland, which once labelled itself 'the least trusted company in the least trusted sector of the economy' (McEwan, 2014), is now moving to articulate how it creates value for customers and society through integrated
KPMG, 2015). This is supported by research from Nanyang University which explored the South African market, where integrated reporting is part of the stock exchange listing requirements. Again, companies benefited from higher share price performance, on average $9 \%$ higher than that of their non-integrated reporting counterparts.

Research by Harvard Business School demonstrates that companies applying the concepts of integrated reporting are more likely to attract long-term investors (Serafeim, 2015). KPMG France has released a study outlining the benefits to companies of attracting such long-term investors, including helping insulate management from market changes by reducing the share price change when earnings expectations are adjusted. A reduced sensitivity to market fluctuations allows management more freedom to manage the business for the sustainable and strategic long term (Garel and Rerolle, 2016).

Investor interest and understanding of the importance of basing investment decisions on more than just financial information is growing steadily. An EY survey found that $92 \%$ of investors believe that public company CEOs should lay out an explicit strategy for long-term value creation and directly affirm that the company's board has reviewed it (EY, 2017).

The study 'Why and how investors use ESG information: evidence from a global survey' similarly demonstrates that investor approaches are also evolving, with $61.2 \%$ of investors believing that the full integration of ESG (environmental, social and governance) strategies into individual stock valuation will have a positive effect. This is compared to $39.1 \%$ of investors who think that the more traditionally used negative screening approach has a positive effect (Amel-Zadeh and Serafeim, 2017).

\section{Investor interest}

We have some way to go before this approach is fully mainstream in the investor community, but significant progress is being made. We are calling on investors to signal their support for this shift by joining leading investor organisations such as VicSuper, New Zealand Superannuation, Aberdeen Standard Investments, PGGM Investment Management, Cbus Super and Hermes, among many others, who have confirmed that their investment processes require information on business models, strategy and the resources on which a business relies through support of integrated reporting (International Integrated Reporting Council, 2017). The International Corporate Governance Network, the premier international industry body for the main global investors, this year endorsed integrated reporting at its annual conference in Malaysia.

Business uptake of integrated reporting has mainly been voluntary. The biggest drive for its adoption has come in markets where it is recognised as an essential and inseparable part of corporate governance. Corporate reporting is the outcome of a corporate governance process grounded in the purpose, values and activities of the business and reflecting the thinking from the board and management team through the business. It is what we call 'integrated thinking', and helps to ensure that the business is focused on a holistic strategy for value creation, which forms the basis of an integrated report. 
Global accounting and auditing standard setters

This trend is not going unrecognised internationally by accounting standard setters. The chair of the International Accounting Standards Board (IASB), Hans Hoogervorst, has reiterated in public speeches throughout 2017 that financial reporting is not sufficient for understanding value creation. Hoogervorst has stated: 'Users will need information about a company's intangibles - strategy, business model or technical know-how ... Users also want to know about the external environment - competition or economic developments - in which a company operates... These elements are often included in integrated reporting' (Hoogervorst, 2017). The IASB has announced that it will revise and update its practice statement on management commentary in an effort to take into account developments in wider reporting, such as integrated reporting. The International Auditing and Assurance Board has advised on the issue of auditing non-financial information and has a specific working group focusing on integrated reporting. Currently, companies adopting integrated reporting are being satisfactorily audited and boards and auditors are comfortable that current standards are applicable and useful.

\section{Overseas uptake}

In Japan, integrated reporting has become the accepted business language of modern corporate governance, with over 300 listed companies now producing integrated reports (Corporate Value Reporting Lab, 2017). It is leading to significant improvements in the quality of dialogue between businesses and investors. In Malaysia the Securities Commission has recognised the importance of integrated reporting as a means of attracting capital and enhancing communication with key stakeholders. As a result, Malaysian companies are being called on to adopt integrated reporting as part of the Malaysian corporate governance code (Suruhanjaya Sekuriti, 2017).

In the Netherlands, a third of listed companies now produce an integrated report, with the corporate governance code speaking the language of integrated reporting by emphasising long-term value creation (Frijns Committee, 2016).

Uptake in India has been driven by a circular issued in February 2017 by the Securities and Exchange Board (SEBI), calling on the top 500 companies to start practicing integrated reporting. SEBI based this decision on its belief that integrated reporting helps companies commit to principle 16 of the global principles of securities regulation produced by the International Organization of Securities Commissions, which states that 'There should be full, accurate and timely disclosure of financial results, risks and other information which is material to
Financial, General Electric, the World Bank and Jones Lang La Salle are working towards integrated reporting.

When the IIRC was formed, one of the key drivers was a perceived regulatory burden that had caused reporting to become a compliance issue. Regulatory demands for transparency had led to voluminous, uncommunicative boxticking reports that were no longer being used for their original purpose, communicating with shareholders. When challenged on the length of General Electric's 2013 annual report, then chief financial officer Jeffrey Bornstein stated: 'Not a retail investor on planet Earth could

\section{Eight of the N100 companies produce integrated reports, with a further 40 organisations in the public and private sectors now working towards it.}

investors' decisions' (International Organization of Securities Commissions, 2010). This call from SEBI has led to some of India's biggest companies producing an integrated report, such as Tata Steel, Mahindra Mahindra, ITC, Reliance Industries and YES Bank.

Companies listed on the Johannesburg stock exchange are required to produce an integrated report on a comply and explain basis. While the IIRC isn't currently calling for integrated reporting to be mandated, the unique history and market of South Africa has meant that asking companies to produce an integrated report has had significant benefits for the country. An increasing body of evidence from the country demonstrates that an integrated and inclusive corporate governance system delivers practical benefits to business and investors.

Other countries where the adoption of integrated reporting continues to build include France, where half of the top 40 listed companies produce integrated reports; the United Kingdom, where requirements to produce a 'strategic report' are closely aligned to the International $<\mathrm{IR}>$ Framework; and the United States, where big names such as Pepsi, Prudential get through it, let alone understand it' (Monga and Chasan, 2015).

Anecdotes such as this have led the IIRC and others to conclude that further regulation in this field is not the answer. The IIRC is therefore engaging with the regulatory market to encourage it to remove any barriers to the adoption of integrated reporting and signpost towards the $<\mathrm{IR}>$ Framework, without making it compulsory. With practice still in its early days, the goal continues to be encouraging further innovation in the field. At this stage, corporate governance codes continue to be the best way to ensure that companies are thinking strategically about their reporting. 2018 will therefore likely see further voluntary adoption, with companies using integrated reporting to go one step ahead of regulations such as the European Union's non-financial reporting directive, which is coming into effect now. Another example will likely be the Ministry of Finance of the People's Republic of China's encouragement for Chinese companies to adopt it as part of its 13th five-year plan for accounting reform and development (Ministry of Finance of the People's Republic of China, 2016). 


\section{New Zealand uptake}

The uptake in New Zealand is also starting to swell. Eight of the N100 companies produce integrated reports, with a further 40 organisations in the public and private sectors now working towards it. The NZX Corporate Governance Code (NZX, 2017) recommends that companies report against a recognised international reporting initiative such as Integrated Reporting. The Institute of Directors in New Zealand is currently planning an education programme around integrated reporting for company board members, while the IIRC's own accredited training partners will begin courses in the country in February 2018.

Recognised internationally as an example of best practice in integrated reporting is New Zealand seafood company Sanford, which clearly lays out its strategic objectives, explaining their importance to the ongoing viability of the company and highlighting the key initiatives that will be implemented in order to achieve them.
Moana Fisheries has also recognised the value of integrated reporting. Zealandia's first integrated report has also been praised, and New Zealand Post has been recognised as a leader in integrated reporting in New Zealand.

\section{Conclusion}

All of these efforts are focused on a desire from the global coalition behind integrated reporting to effect real change in our markets, with the twin goals of financial stability and sustainable development encouraging trust and securing the future of our markets. Integrated reporting focuses on identifying, isolating and managing risks and taking advantage of opportunities, making sure businesses have a holistic understanding of the external environment in which they operate and access to the multiple resources they need to strive and thrive in the future.

When companies are thinking in this way, they are better placed to run their business sustainably. They understand the interconnectivity of information, and the trade-offs they have to make every day; how they are creating value not just for the business, but for others as well. Integrated reporting allows the company to articulate the value it creates to its shareholders, its stakeholders and to the society in which it operates, over the short, medium and long term. We live in a world of 24-hour news cycles: either a company is willing to communicate its own story to the world, or it is content to let others do it for it.

I urge business leaders reading this article to evaluate your own reporting practices. I am confident that integrated reporting is becoming the global norm for reporting and a badge of good governance globally. In an internationally competitive market, the benefits emerging from markets where it is now best practice are too positive to ignore. An increasing number of New Zealand companies are already demonstrating global best practice in adopting integrated reporting and I recommend you join them now.

\section{References}

Amel-Zadeh, A. and G. Serafeim (2017) 'Why and how investors use ESG information: evidence from a global survey', Harvard Business School Accounting and Management Unit working paper

Corporate Register (2017) 'International Integrated Reporting Council (IIRC): integrated reporting', www.corporateregister.com/frameworks/ iirc

Corporate Value Reporting Lab (2017) 'Self-expressed integrated report issuing company 2017 edition', 10 November (in Japanese)

EY (2017) Is Your Nonfinancial Performance Revealing the True Value of Your Business to Investors?, EY

Frijns Committee (2016) Dutch Corporate Governance Code, December

Garel, A. and J-F. Rerolle (2016) 'When fundamental investors relieve market pressures on management: evidence from France', 15 July

Hoogervorst, H. (2017) 'The IASB and integrated reporting', speech to the International Integrated Reporting Council meeting, New York, 26 April, http://archive.ifrs.org/About-us/IASB/Members/Documents/ hans-hoogervorst-integrated-reporting-april-2017.pdf

International Integrated Reporting Council (2013) The International $<\mid R>$ Framework, London: IIRC

International Integrated Reporting Council (2017) 'Investors support Integrated Reporting as a route to better understanding of performance', 2 September

International Organization of Securities Commissions (2010) 'Objectives and principles of securities regulation', June

Lee, K-W. and G. Yeo (2015) 'The association between integrated reporting and firm valuation' Review of Quantitative Finance and Accounting, September, pp.6-7

McEwan, R. (2014) 'Ross McEwan's speech at The Trampery', London, 27 February

Ministry of Finance of the People's Republic of China (2016) 'Outline for the Thirteenth Five-Year Plan for Accounting Reform and Development'

Monga,V. and E. Chasan (2015) 'The 109,894-word annual report' Wall Street Journal, 2 June

National University of Singapore and KPMG (2015) Towards Better Business Reporting: integrated reporting and value creation, National University of Singapore Business School Department of Accounting and KPMG

NZX (2017) NZX Corporate Governance Code

Ocean Tomo (2017) 'Intangible Asset Market Value Study', http://www. oceantomo.com/intangible-asset-market-value-study/

Securities and Exchange Board of India (2017) 'Integrated reporting by listed entities', 6 February

Serafeim, G. (2017) 'Integrated reporting and investor clientele', Journal of Applied Corporate Finance, 2 (2), Spring

Suruhanjaya Sekuriti (Securities Commission Malaysia) (2017) Malaysian Code on Corporate Governance, April 